\title{
An Annotated List of Auchenorrhyncha and Heteroptera Collected in the Coastal Salt Marshes of the Mississippi Delta in Louisiana
}

\author{
I. M. Sokolov $(\mathbb{D}$, X. Chen, R. M. Strecker, and L. M. Hooper-Bùi \\ Department of Environmental Sciences, LSU College of the Coast \& Environment, 1002-Q Energy, Coast \& Environment Building, \\ Baton Rouge, LA 70803, USA
}

Correspondence should be addressed to I. M. Sokolov; isokolovl@lsu.edu

Received 21 September 2017; Revised 6 November 2017; Accepted 26 November 2017; Published 4 January 2018

Academic Editor: Ai-Ping Liang

Copyright ( 2018 I. M. Sokolov et al. This is an open access article distributed under the Creative Commons Attribution License, which permits unrestricted use, distribution, and reproduction in any medium, provided the original work is properly cited.

\begin{abstract}
Insects that live in the saltwater and brackish marshes, which fringe the northern coast of the Gulf of Mexico, are largely unstudied. During 2011-2013, a survey of insect fauna of the coastal salt marshes of the Mississippi Delta in Louisiana was conducted. We present the species of terrestrial representatives of Heteroptera and Auchenorrhyncha collected during that study. The Auchenorrhyncha are represented by 33 species in 6 families, with Cicadellidae (16 species) and Delphacidae (13 spp.), and are the most diverse. The terrestrial heteropterans are represented by 11 species in 5 families with the majority of species in Miridae (6 spp.). A list of species, annotated with numbers of specimens collected, ranges of collection dates (seasonality), and published information on their hosts, habitats, and ranges, is presented. Of 44 identified species, ten species (22.7\%) are reported from Louisiana for the first time. The paper provides evidence of a diverse terrestrial arthropod community in brackish marshes; a community that is largely understudied.
\end{abstract}

\section{Introduction}

Louisiana's coastal marshes are experiencing the highest rate of wetland loss in the US [1] mainly due to sea level rise and dynamic geomorphology, but also due to natural and human-induced disasters $[2,3]$. Through the previous and 2017 Louisiana Coastal Master Plan, marsh restoration is ongoing to combat human-caused and natural land loss. As a consequence of the rising concern over loss of habitat, there is a focus on counteracting that loss via restoration and achieving a sustainable ecosystem within the coastal Louisiana. Furthermore, there is a strong need for adequate and accurate assessment of natural processes in fragile and valuable Louisiana wetlands $[4,5]$. Such studies are not only critical in designing effective reserve systems for potential ecosystem restoration, but also necessary in many conservation and ecological studies [6, 7]. Together with annelids, mollusks, and crustaceans, terrestrial arthropods are critical ecosystem components due to their high diversity and sensitivity to perturbations [8]. Within Louisiana coastal ecosystems, terrestrial arthropods represent a major component of multicellular biodiversity with dominating roles of representatives of Hemiptera and Diptera [9]. However, cataloged and published data on arthropod fauna of the coastal Louisiana salt marshes are still scarce and hard to find. Information on the arthropod representatives of this ecosystem is scattered across many literature sources and is practically hidden from research.

During the years 2011-2013 thousands of insects were collected by the Hooper-Bùi research team (LSU, Baton Rouge) as a part of a project dedicated to assessing the ecological impact of hurricanes and oil spill contamination on salt marsh ecosystems in the Mississippi Delta. This paper presents the result of taxonomic treatment of the collected representatives of Auchenorrhyncha and Heteroptera, main suborders of the order Hemiptera. This is the first annotated list of leaf- and planthoppers and true bugs, inhabiting coastal salt marshes in Louisiana. Host and range analyses were completed to compare peculiarities of difference in species 
relative abundance between Louisiana coastal salt marshes and other coastal regions of the USA.

\section{Material and Methods}

2.1. Study Area. The modern Mississippi Delta configuration is a result of the Holocene major shifts in the river's course and associated land building and land loss ended in formation of five delta complexes [10]. In this study, we investigated marsh systems formed in the modern Balize delta lobe (active $\sim 1000$ yr BP to present) [10]. Field studies were conducted in Spartina marshes at sites established within Barataria Bay (13 sites; $29.43^{\circ} \mathrm{N} 89.83^{\circ} \mathrm{W}$ ) and Breton Sound (5 sites; $29.52^{\circ} \mathrm{N}$ $89.61^{\circ} \mathrm{W}$ ) areas (Plaquemines Parish, Louisiana). Currently both Barataria Bay and Breton Sound are in a similar state of deterioration via subsidence and land loss, and their land areas are represented by a number of flat islands occupied by marshes some of which are converted to open-water [11].

2.2. Site Descriptions. All sites were established in saline to brackish Spartina marshes. In Barataria Bay saltmarshes predominate, which has a low vertical tidal range $(<50 \mathrm{~cm})$. Dominant vegetation at these sites was represented by Spartina alterniflora Loisel., Distichlis spicata (L.) Greene, and Avicennia germinans (L.) L. [12]. Breton Sound is a brackish marsh with low vertical tidal range and freshwater inputs from the Mississippi River. Sometimes, during summer, water levels drop below the elevation of the marshes and marshes are dry. Dominant vegetation at Breton Sound sites was represented by Spartina patens (Aiton) Muhl., S. alterniflora, Juncus roemerianus Scheele, and Bolboschoenus robustus (Pursh) Soják [12].

2.3. Sample Collections. The arthropod community was collected during 2011, 2012, and 2013. Sites were marked using vertical PVC pipes at each end of the transect for repeated sampling at the same plots. Insects were collected between 6:30 am and 12:00 pm when the temperature ranged from $22^{\circ} \mathrm{C}$ to $34^{\circ} \mathrm{C}$. Sites in Barataria Bay and Breton Sound were visited on consecutive days. Sweep net collections were conducted using a $38.1 \mathrm{~cm}$ (15 in) diameter collapsible insect collection net $\left(1140.1 \mathrm{~cm}^{2}\right.$, Bioquip Products Inc., Rancho Dominguez, CA). One collection consisting of two, $20 \mathrm{~m}$ transects was made by sweeping with a standard net through the upper two-thirds of Spartina along each transect at each of the sites. Collection transects ran perpendicular to the edge of the marsh starting at the edge and walking inland to reduce possible edge-effects. Collected terrestrial arthropods were transferred from the net into plastic ziplock bags filled with 95\% ethanol and then transported to the lab at Louisiana State University and stored in vials with 95\% ethanol.

2.4. Species Identification. The insects were identified using appropriate taxonomic keys and resources: to the genus level using Bartlett et al. [13] for Fulgoroidea, Dietrich [14] for Cicadomorpha, DeLong [15] for Cicadellidae, and Blatchley [16] for Heteroptera and to species level using corresponding taxonomic keys found in the taxonomic revisions of each genera, for example, in Beamer [17], in Kelton [18], and in
Bartlett and Webb [19], or regional reviews of fauna, for example, for Illinois [15], Florida [20], and Cuba [21]. Most species identifications were based on male genitalia; in a case of male absence from the material, species identifications were based on the shape of female ovipositor when it gives reliable characters. Due to taxonomic difficulty, preimaginal stages were not identified. Voucher specimens are deposited partially in the Insect Collection of the Illinois Natural History Survey (INHS, Champaign, IL), where specialists kindly confirmed our identifications, and partially in the LSU Arthropod Museum (LSAM, Baton Rouge, LA).

2.5. Presentation of the Material. To characterize examined material, we divided all identified species into four abundance classes. Dominant species were those with a total number of collected specimens $(n)>1000$; subdominant species were those with total number of collected specimens $1000 \leq n$ $\geq 100$; regular species were those with total number of collected specimens $100 \leq n \geq 10$; rare species were those with total number of collected specimens $<10$. Within each classification, insect abundance-host (plant or insect) and insect abundance-range patterns were analyzed. Practically, in the case of the abundance-host pattern, we compared changes in proportions between herbivores and predators, between grass feeders and polyphagous species, and between specialized salt marsh sap-feeders and grass generalists; in the case of the abundance-range pattern, we compared changes in proportion between coastal species and noncoastal species of different origin among above-mentioned categories of abundance. Under the term "coastal species," we consider species whose ranges include Atlantic and/or Gulf Coast States; under the term "noncoastal species," we consider species distributed in coastal states and also in the eastern and/or midwestern states, or characterized by transcontinental distribution (from Atlantic to Pacific Coasts).

In the list, the dates are presented without regard to the year of collection; in a case of several collection dates the dates are presented as a range; in a case if one or two dates are available, dates are listed as they are.

\section{Results}

More than 20,000 specimens of all stages of insects belonging to the suborders Auchenorrhyncha and Heteroptera from almost 300 samples were examined during this study. Examined material included 4052 adult specimens of Auchenorrhyncha, represented by 33 species within 6 families, and 13403 specimens of Heteroptera, represented by 11 species within 5 families. The majority of identified species belonged to three families: Cicadellidae (16 species), Delphacidae (13 species), and Miridae (6 species).

\subsection{Auchenorrhyncha}

\subsubsection{Fulgoroidea}

Delphacidae

(1) Keyflana hasta Beamer, 1950

Relative abundance: 6 specimens (in INHS, LSAM). 
Collection dates: 1 September-16 October.

Hosts: Denno et al. reported insects feeding on black needlerush (Juncus roemerianus Scheele) [22].

Habitat: it inhabits salt coastal marshes [22].

Regional distribution: described from Cedar Keys, Florida [23]. Distributed in the eastern USA from Maryland southward to Florida Peninsula [13, 24].

It is a new state record, which extends the known range of the species approximately 400 miles in westward direction.

(2) Megamelus lobatus Beamer, 1955

Relative abundance: one male (in INHS).

Collection dates: 13 September.

Hosts: this species feeds on saltmeadow cordgrass (Spartina patens) [25].

Habitat: it occurs in coastal habitats.

Regional distribution: described from Cedar Keys, Florida, and Slidell, Louisiana [17]. The range of species extends from New Hampshire southward to Florida and along the Gulf States to Texas [13].

(3) Megamelus longicornis (Dozier, 1922)

Relative abundance: 26 specimens (in INHS, LSAM).

Collection dates: 15 August-13 September.

Hosts: they are unknown.

Habitat: it is unknown, presumably coastal species.

Regional distribution: endemic of the western Gulf States. Type specimen of this species was collected in Ocean Springs, Mississippi [26], but has been lost. Neotype was designated on the basis of specimens originated from Covington, Louisiana [17]. As far as known, the species is limited in its distribution to three western Gulf States: Mississippi, Louisiana, and Texas $[13,24]$.

(4) Metadelphax propinqua (Fieber, 1866)

Relative abundance: 17 specimens (in INHS, LSAM).

Collection dates: 14 August-4 February.

Hosts: polyphagous species, feeding is reported on about 15 grass species, including agricultural crops like sugarcane (Saccharum officinarum L.), barley (Hordeum vulgare L.), Bermuda grass (Cynodon dactylon (L.) Pers.), maize (Zea mays L.), rice (Oryza sativa L.), and coastal graminoids like chairmaker's bulrush (Schoenoplectus americanus (Pers.) Volkart), and seashore saltgrass (Distichlis spicata) [28].

Habitat: coastal areas and agricultural landscapes.

Regional distribution: cosmopolitan species, described from Southern and Central Europe [27] and known from warm temperate and tropical zones of all continents: Africa, Asia, Australia, Europe, North, and South Americas; in North America it belongs to a transcontinental species reaching northward into Canada [13].
Economic importance: on agricultural crops $M$. propinqua is known as a vector of few viruses like cynodon chlorotic streak virus in corn and bermudagrass and maize rough dwarf virus [29].

(5) Neomegamelanus elongatus (Ball, 1905)

Relative abundance: 22 specimens (in INHS, LSAM).

Collection dates: 14 August-4 February.

Hosts: presumably feeds on Spartina patens [31].

Habitat: inhabits coastal marshes.

Regional distribution: this species was described from Biscayne Bay, Florida [30], and is widely distributed along the Atlantic and Gulf Coasts northwards to Massachusetts and westward to Louisiana [13, 24].

(6) Neomegamelanus spartini (Osborn, 1905)

Relative abundance: one male and one female (in INHS, LSAM).

Collection dates: 13 September.

Hosts: Wilson recorded Spartina patens [25] as the host plant.

Habitat: inhabits coastal marshes.

Regional distribution: described from New York [32] and is widely distributed along the Atlantic Coast from Maine southward to Florida and along the Gulf Coast westward to Louisiana [13, 24].

(7) Perkinsiella saccharicida Kirkaldy, 1903

Relative abundance: one male (in INHS).

Collection dates: 6 September.

Hosts: sugarcane is reported as the preferred host plant for this species and also it was recorded from corn [33].

Habitat: agricultural landscapes.

Regional distribution: cosmopolitan species, described from the Hawaiian Islands [34] and distributed across the tropical parts of Asia, Australia, Africa, the Middle East, and both Americas in regions where sugarcane is grown [13]. P. saccharicida was firstly introduced into continental USA in Florida in the early 1980s [35]; in Louisiana the pest was firstly recorded in 1994 [36]; modern distribution in the USA is limited to Gulf States [13].

Economic importance: the species is an important pest of sugarcane and it is a vector of sugarcane fiji disease virus, which causes severe yield losses [37].

(8) Prokelisia crocea (Van Duzee, 1897)

Relative abundance: three specimens (in INHS, LSAM).

Collection dates: 14 September.

Hosts: Holder and Wilson reported the prairie cordgrass Spartina pectinata Link. as the host plant [39].

Habitat: inhabits grasslands. 
Regional distribution: described from Iowa [38]. Widespread across the eastern and midwestern states of the USA, westward to North Dakota, Colorado, New Mexico, and Louisiana and northward to southern Canada [40].

(9) Prokelisia dolus Wilson, 1982

Relative abundance: 1560 specimens (in INHS, LSAM).

Collection dates: 1 April-4 February.

Hosts: Wilson reported Spartina alterniflora as the main host of the species [25]

Habitat: coastal species and one of the most abundant herbivorous insects in Spartina marshes [41].

Regional distribution: described from Maryland rather recently [40] and widely distributed along the Atlantic and Gulf Coasts, reaching northward into the southern Canada and southward into Mexico [13]; also, unintentionally, this species was introduced into California [40].

(10) Prokelisia marginata (Van Duzee, 1897)

Relative abundance: 1180 specimens (in INHS, LSAM).

Collection dates: 1 April-19 October.

Hosts: this species is recorded on different species of Spartina: S. alterniflora, S. patens, S. foliosa Trin., S. maritima (Curtis), S. anglica C. E. Hubb. [25, 42].

Habitat: it is primarily a coastal species and one of the most abundant herbivorous insects in Spartina marshes [41].

Regional distribution: this species was described from New Jersey and New York [38] and is widespread across the eastern and southern states of Atlantic and Gulf Coast [40] and also was introduced into California [13] and Western Europe [42].

Economic importance: together with $P$. dolus this species was considered to be a potential biological agent for control invasive Spartina species [43]. Also, both species are being used extensively as an ecological models over nearly 30 years by Denno and colleagues (see Eubanks et al. [44]), particularly as models for tritrophic ecological interactions between habitat and life history parameters.

(11) Sogatella molina (Fennah, 1963)

Relative abundance: one female (in INHS).

Collection dates: 14 August.

Hosts: native host plants for this species are unknown, but they were collected from invasive California grass Panicum purpurascens Raddi (=Urochloa mutica (Forssk.) T. Q. Nguyen) [45]. Congeners of this species are important pests of many agricultural cereals, like rice, wheat, and corn [46-48].

Habitat: they are agricultural and urbanized landscapes.
Regional distribution: this species was described from Mexico [45]. It is distributed in Central America and West Indies reaching into the southern United States northward to South Carolina and westward to Mississippi [13].

It is a new state record, representing the most western locality of the species in the USA.

(12) Spartidelphax detectus (Van Duzee, 1897)

Relative abundance: 1012 specimens (in INHS, LSAM).

Collection dates: 1 April-4 February.

Hosts: Bartlett and Webb reported this species from Spartina alterniflora and S. patens; also it was collected from Distichlis spicata [19].

Habitat: it is coastal species.

Regional distribution: this species was described from New York [38] and widespread across Atlantic and Gulf Coast states [19] and also in West Indies [13]. Very often it appears in great numbers and together with representatives of Prokelisia shapes a major portion of all herbivores in Spartina salt marshes [49].

(13) Saccharosydne saccharivora (Westwood, 1833)

Relative abundance: one male (in INHS).

Collection dates: 6 September.

Hosts: the species is a major pest of sugarcane, but its original host plants are considered to be Andropogon bicornis L. and A. glomeratus (Walter) Britton [51]; also the species is recorded on Sorghum sudanense (Piper) Stapf. (=Sorghum $\times$ drummondii (Nees ex Steud.) Millsp. \& Chase) [52].

Habitat: it is agricultural landscapes.

Regional distribution: it is new World species described from West Indies [50] and is distributed across the historical and modern range of sugarcane cultivation: northern South America, Central America, and West Indies, reaching into the Atlantic and Gulf Coast states of USA, including Louisiana, northward to Maryland [13].

Economic importance: this planthopper is a vector of sugarcane yellow leaf phytoplasma, a dangerous disease, causing vegetation losses from $30 \%$ to over $60 \%$ of susceptible varieties [53].

Dictyopharidae

(14) Rhynchomitra recurva (Metcalf, 1923)

Relative abundance: one male and one female (in INHS, LSAM).

Collection dates: 1 July, 1 September.

Hosts: native host plants for this species are unknown, but it was recorded on an introduced weeping lovegrass (Eragrostis curvula (Schrad.) Nees) [55]. 
Habitat: it is unknown.

Regional distribution: this species was described from North Carolina [54]. It is native to the south-eastern North America ranging from Texas and Louisiana northward to North Carolina [13].

\section{Flatidae}

(15) Metcalfa pruinosa (Say, 1830)

Relative abundance: one female (in INHS).

Collection dates: 15 August.

Hosts: the species has common name "citrus flatid planthopper" and was reported from only cultivated Citrus trees [57], but it feeds on many trees, shrubs, and some herbs. In Illinois, host plants were recorded as 85 species in 45 families [58]. During a survey of tidal marshlands in Mississippi M. pruinosa was swept from Baccharis halimifolia [59].

Habitat: it is wooded natural and agricultural landscapes.

Regional distribution: transcontinental species is described from "United States" in 1830 [56] and is widely distributed in North America reaching northward into southern Canada; also it is adventive in southern Europe and Korea [13].

Economic importance: the species is of limited economic importance in North America, is a nonvector, and ordinarily does very little damage to hosts [57].

\section{Cicadellidae}

(16) Agallia nielsoni Freytag, 2003

Relative abundance: one female (in INHS).

Collection dates: 14 August.

Hosts: host plant is unknown, but representatives of the genus feed on a wide variety of plants, mostly legumes. In a case of high abundance, $\mathrm{Ag}$. nielsoni may also affect cereal, forage, and truck crops [60].

Habitat: it is unknown.

Regional distribution: this subtropical species was described from Honduras [61] and widely distributed across northern South America, Central America, Mexico,and south Texas [61], as Ag. lingula Van Duzee was recorded for Natchitoches Parish, Louisiana [60], but without subsequent confirmation [61]. The discovery of Ag. nielsoni in Plaquemines Parish indicates the presence of this species in Louisiana and represents the most north-eastern locality of the species in the USA.

(17) Amplicephalus (Amplicephalus) littoralis (Ball, 1905)

Relative abundance: 120 specimens (in INHS, LSAM).

Collection dates: 1 April-19 October.
Hosts: saltmeadow cordgrass Spartina patens is reported to be a host plant [62]; also the species was collected from Distichlis spicata [63].

Habitat: it is coastal species.

Regional distribution: the species was described from New Jersey [30] and occurs in the Atlantic and Gulf Coast states from Quebec in the north to Mississippi in the south-east [33].

It is a new state record, representing the most western locality of the species in the USA.

(18) Balclutha frontalis (Ferrari, 1882)

Relative abundance: 12 specimens (in INHS, LSAM). Collection dates: 6 September-19 October.

Hosts: this species feeds on sugarcane, Sorghum sp., Panicum barbinode Trin. (=Urochloa mutica (Forssk.) T. Q. Nguyen), and Setaria viridis (L.) P. Beauv. (as Balclutha rosea [65]).

Habitat: it is grasslands.

Regional distribution: cosmopolitan species is described from Italy [64] and is widely distributed in the tropical and adjacent temperate zones of all continents [33]. In North America B. frontalis occurs in states along the Gulf of Mexico and Atlantic Coasts northward to Virginia and also in California and Nevada (as Agellus guajanae [66]).

(19) Balclutha neglecta (DeLong \& Davidson, 1935)

Relative abundance: one male and one female (in INHS, LSAM).

Collection dates: 12 and 20 September.

Hosts: the species was collected from sugarcane in Texas [67].

Habitat: it is grasslands.

Regional distribution: transcontinental species described from Colorado (as Agellus neglectus [66]) and is widespread in North America ranging from Canada southward to Guatemala in Central America and Puerto Rico in West Indies [33].

(20) Balclutha sp.

Relative abundance: one female (in INHS).

Collection dates: 15 August.

(21) Draeculacephala floridana Ball, 1900

Relative abundance: 54 specimens (in INHS, LSAM).

Collection dates: 1 April-29 September.

Hosts: Rossi and Strong reported Spartina alterniflora the host plant, also the species was reported from Salicornia virginica L., Batis maritima L., Distichlis spicata, and Borrichia frutescens (L.) de Candolle [68].

Habitat: it is coastal marshes.

Regional distribution: it was described from Florida [69] and until now was known for Florida and Texas only [70]. 
It is a new state record. This locality is situated within the known species range.

(22) Draeculacephala portola Ball, 1927

Relative abundance: 7 specimens (in INHS, LSAM).

Collection dates: 9 April-1 July.

Hosts: they are unknown.

Habitat: it is coastal marshes.

Regional distribution: this species was described from Florida [71]. Previously, it was considered to be a widespread central and eastern species common on agricultural crops $[67,72]$. After a genus revision and species reclassification it turned out that D. portola is a species from coastal habitats of the Atlantic Coast [73]. Until present, the species was known from southern Delaware to northern Florida [70].

It is a new state record, which extends the known range of species approximately 400 miles in westward direction.

(23) Empoasca (Empoasca) solana DeLong, 1931 Relative abundance: 12 specimens (in INHS, LSAM). Collection dates: 15 August.

Hosts: it is a polyphagous species; feeding is recorded on a wide variety of trees, shrubs, and herbs, including many agricultural crops like cotton, potato, alfalfa, and spinach [33].

Habitat: it is eurytopic.

Regional distribution: this species was described from Baton Rouge, Louisiana [74]. It belongs to the species with transcontinental distribution ranging in North America from southern Canada southward into Central America and northern South America [75, 76].

(24) Exitianus exitiosus (Uhler, 1880)

Relative abundance: one male (in INHS).

Collection dates: 14 August.

Hosts: this species feeds on bermudagrass Cynodon dactylon (L.) Pers. and green foxtail Setaria viridis (L.) Beauv. and also is reported from small grains, like spring wheat, barley, and oat [78].

Habitat: it is grasslands and agricultural landscapes.

Regional distribution: transcontinental species is described from Maryland [77] and is widespread in North America reaching northward into Canada and southward into Mexico and West Indies [33, 79].

It is a new state record. This locality is situated within the known species range.

(25) Graminella nigrifrons (Forbes, 1885)

Relative abundance: three specimens (in INHS, LSAM).

Collection dates: 6 and 20 September.
Hosts: feeding is recorded on a wide variety of graminoids, including such agricultural crops as oats, barley, maize, sugarcane, and others [81].

Habitat: it is grasslands.

Regional distribution: transcontinental species is described from Illinois [80] and is widespread in North America ranging from Canada southward to Mexico and West Indies [33, 82].

Economic importance: the species is a vector of maize chlorotic dwarf virus and maize bushy stunt phytoplasma [83].

(26) Graminella sonora (Ball, 1900)

Relative abundance: one male (in INHS).

Collection dates: 6 September.

Hosts: the species is a grass generalist and was reported from Johnsongrass Sorghum halepense (L.) Pers., wild cane S. bicolor (L.) Moench., sudangrass S. sudanense (Piper) Stapf., corn, oat, wheat [85], bermuda grass [86], and sugarcane [67].

Habitat: it is grasslands.

Regional distribution: transcontinental species is described from Arizona [84] and is widespread in North America ranging from the northern USA (Minnesota) southward to Costa Rica in Central America and Puerto Rico in West Indies [33].

Economic importance: the sorghum stunt mosaic rhabdovirus may be transmitted [85].

(27) Haldorus (Eohaldorus) australis (DeLong, 1926)

Relative abundance: one male (in INHS).

Collection dates: 14 August.

Hosts: they are unknown.

Habitat: it is grasslands.

Regional distribution: this species was described from Florida [87] and in the continental USA is recorded also for Louisiana and Mississippi; outside it is known from Puerto Rico in West Indies [33].

(28) Negosiana miliaris (Stål, 1864)

Relative abundance: one female (in INHS).

Collection dates: 28 September.

Hosts: they are unknown.

Habitat: it is unknown.

Regional distribution: the species was described from Mexico [88]. Records on this species are scattered along the coastal states: Connecticut, Virginia, North Carolina, Florida, Georgia, and Texas [33], but also the species is known on one male from Illinois (as Gypona (Prairiana) miliaris [89]).

It is a new state record. This locality is situated within the known species range.

(29) Sanctanus fusconotatus (Osborn, 1922)

Relative abundance: 8 specimens (in INHS, LSAM). 
Collection dates: 14 August-3 October.

Hosts: the host plant for this leafhopper is not known. The closest in genitalia morphology and allopatric $S$. aestuarium (DeLong and Sleesman) is recorded on the cordgrass (Spartina sp.) [91], while more distant S. fasciatus (Osborn) and S. sanctus (Say) were recorded on Cyperus rotundus L. and C. esculentus L., respectively [92].

Habitat: it is coastal species.

Regional distribution: the species was described from Cameron Parish, Louisiana [90]. So far it is known from Louisiana only and may be considered as a local coastal endemic species $[33,93]$.

(30) Spangbergiella vulnerata (Uhler, 1877)

Relative abundance: 16 specimens (in INHS, LSAM).

Collection dates: 9 April-1 September.

Hosts: this species was recorded from St. Augustine grass (Stenotaphrum secundatum (Walter) Kuntze) [95].

Habitat: it is grasslands.

Regional distribution: this species was described from Central Texas [94] and is widely distributed across the midwestern and eastern states in the USA, Mexico, West Indies, and South America [33, 96].

(31) Xyphon reticulatum (Signoret, 1854)

Relative abundance: one male and one female (in INHS, LSAM).

Collection dates: 1 July and 14 October.

Hosts: this is a polyphagous species recorded on many herbaceous hosts including cordgrass, bermudagrass, cane, alfalfa, and potato [33, 98].

Habitat: it is grasslands and agricultural landscapes.

Regional distribution: transcontinental species is described from Cuba [97] and is widespread in New World ranging from the northern states in the USA south through Central America and West Indies to Brazil and Chile [33].

\subsubsection{Cercopoidea}

\section{Clastopteridae}

(32) Clastoptera xanthocephala Germar, 1839

Relative abundance: one female (in INHS).

Collection dates: 15 August.

Hosts: this spittlebug feeds on the aerial parts of many trees, shrubs, and grasses [99], but favorite hosts are considered to be sunflower (Helianthus spp.) and ragweed (Ambrosia sp.) [100]. During survey of tidal marshlands in Mississippi it was swept from Baccharis halimifolia [59].

Habitat: it is eurytopic.
Regional distribution: this species was described from Pennsylvania and "Carolina" [101] and is widespread in the eastern and midwestern states of the USA reaching in southwest direction into Arizona and also is recorded from Mexico [102].

\subsubsection{Membracoidea}

Membracidae

(33) Spissistilus festinus (Say, 1830)

Relative abundance: two females (in INHS, LSAM).

Collection dates: 14 September.

Hosts: Dietrich et al. reported as host plants a wide variety of plants, mostly legumes and grasses, like peanuts Arachis hypogaea L., alfalfa Medicago sativa L., bush clovers Lespedeza spp., common beans Phaseolus vulgaris L., and soybeans Glycine max (L.) Merr. [103].

Habitat: it is grasslands and agricultural landscapes.

Regional distribution: transcontinental species was described from Florida [56] and is widely distributed throughout North and Central Americas from Canada to Mexico [104] reaching southward into Panama [105].

\subsection{Heteroptera}

\subsubsection{Cimicoidea}

Anthocoridae

(1) Orius insidiosus (Say, 1832)

Relative abundance: 55 specimens (in LSAM).

Collection dates: 15 August.

Hosts: both the nymph and adult stages of this species are well-known generalist predators of phytophagous mites [107] and different stages of soft bodied insects, like thrips and aphids [108, 109]. Field researches demonstrated the ability of this predatory species to suppress population of their prey items under natural conditions $[110,111]$.

Habitat: it is eurytopic.

Regional distribution: transcontinental species was described from the "United States" [106] and is widely distributed in North America ranging from southern Canada to the southern borders of the USA; also the species is common elsewhere in Central America, West Indies, and South America [112]. For Louisiana it was recorded by Kelton [113].

Economic importance: as a biocontrol agent, the species is of commercial importance: it is used for mass rearing [114] and is available for mass release in greenhouses, orchards, and gardens [115]. 
(2) Orius pumilio (Champion, 1900)

Relative abundance: 62 specimens (in LSAM).

Collection dates: 15 August.

Hosts: predator of mites, thrips, and aphids is considered to be a useful biocontrol agent against flower thrips in green houses and can be used for mass rearing [117].

Habitat: it is eurytopic.

Regional distribution: central-American species was described from Guatemala [116], reaching northward in the southern United States, from where it was recorded from Florida only $[112,118]$.

It is a new state record, which extends the known range of species approximately 400 miles in westward direction.

Nabidae

(3) Nabis (Tropiconabis) latior Kerzhner and Henry, 2008 Relative abundance: one female (in LSAM).

Collection dates: 10 April.

Hosts: similar to the other representatives of the family, it is supposed to be a generalist predator, feeding on a vast spectrum of small invertebrates, chiefly insects [119]. Its closest relative, N. (Tropiconabis) capsiformis Germar, is considered to be an important biological control agent in soybean fields in Louisiana [120].

Habitat: it is unknown.

Regional distribution: this species has been missed by researchers for a long time and was described from Louisiana less than 10 years ago [121]. Species range occupies all the Gulf States (from Texas eastwards to Florida) and Bahamas [121].

\subsubsection{Lygaeoidea}

Blissidae

(4) Ischnodemus conicus Van Duzee, 1909

Relative abundance: 437 specimens (in LSAM).

Collection dates: 1 April-14 September.

Hosts: this species feeds on Spartina alterniflora [20, 122].

Habitat: it is coastal species.

Regional distribution: the species was described from Galveston, Texas [123], and reported from Louisiana and other Gulf and Atlantic Coastal States north to Virginia and North Carolina [20].

Cymidae

(5) Cymodema breviceps (Stål, 1873)

Relative abundance: one female (in LSAM).
Collection dates: 1 September.

Hosts: adults and nymphs feed on rushes and sedges in damp areas; in the salt marshes they are found to be abundant on Spartina patens and also occur on Distichlis spicata and Juncus roemerianus [125].

Habitat: it is wetlands.

Regional distribution: the species was described on the basis of a series of specimens from Texas and "Carolina meridionalis" (=South Carolina) [124]. It is distributed in the south-eastern part of the United States from New York and Indiana south to Louisiana and Texas; also the species is common in Neotropics reaching southward in Argentine and Chile [20].

\subsubsection{Miroidea}

Miridae

(6) Dagbertus fasciatus (Reuter, 1876)

Relative abundance: 66 specimens (in LSAM).

Collection dates: 15 August.

Hosts: polyphagous species is recorded on different woody plants, such as Cordia nitida Vahl (=Cordia laevigata Lam., Boraginaceae) and Tecoma stans (L.) Juss. (Bignoniaceae) in Cuba [127] or avocado in Florida [128], as well on herbs like Portulaca oleracea L. [129].

Habitat: it is eurytopic.

Regional distribution: the species was described from South Carolina [126] and is widespread in the southern Atlantic and Gulf Coastal States, including Florida, Georgia, Louisiana, Mississippi, and Texas [130].

(7) Rhinacloa clavicornis (Reuter, 1905)

Relative abundance: 6 specimens (in LSAM).

Collection dates: 15 August.

Hosts: this species was recorded from a wide range of hosts, including such agricultural crops as corn, cotton, potato, and bean; also adults are reported from Crotalaria juncea L. (Fabaceae), Ambrosia artemisioides Meyen and Walpers (Asteraceae) [132], and Buddleja wrightii Robbins (= B. sessiliflora Kunth, Buddlejaceae) [21].

Habitat: it is eurytopic.

Regional distribution: this is a tropical species, described from Venezuela [131], and ranging from Argentina to Mexico, West Indies, and Florida [133].

It is a new state record, which extends the known range of species approximately 400 miles in westward direction.

(8) Trigonotylus tenuis Reuter, 1893

Relative abundance: 6 specimens (in LSAM).

Collection dates: 4 May-1 September. 
Hosts: this species feeds on grasses and sedges Bromus arvensis L. (= B. japonicus Thunb.), Digitaria ciliaris (Retz.) Koeler, Hordeum pusillum Nutt., Cyperus rotundus L. (as T. doddi (Distant) in [129]). Also it was reported from invasive grasses Cynodon dactylon (L.) Pers., Eleusine indica (L.) Gaertn. [21], and some agricultural crops like rice [134].

Habitat: it is grasslands.

Regional distribution: cosmopolitan species is originally described from Seychelles Islands [135] and is characterized by pantropical distribution [136], including tropical or subtropical regions of West Indies and Central and South America [137]. In North America, its range occupies Louisiana and other Gulf States and extends northward into Maryland in the east, Nebraska in the midwest, and California in the west [18].

(9) Trigonotylus saileri Carvalho, 1957

Relative abundance: 137 specimens (in LSAM).

Collection dates: 16 March-14 September.

Hosts: Seashore saltgrass Distichlis spicata was recorded as the host plant of this species [136].

Habitat: it is saline wetlands.

Regional distribution: the holotype of this species originates from Maryland [137]; the taxon is native to the coastal states of the eastern and southern North America, including Louisiana and reaching westward Arizona [18]. In the Maritime Provinces, adults were collected on grasses along the upper margins of tidal flats [18].

(10) Trigonotylus uhleri (Reuter, 1876)

Relative abundance: 12,583 specimens (in LSAM).

Collection dates: 16 March-19 September.

Hosts: Denno reported Spartina alterniflora as the host plant [49], on which it can reach very high densities up to 3000 specimens per square meter [138].

Habitat: it is salt coastal marshes.

Regional distribution: the origin of the type series of this species is cited as "Habitat Americam borealem" [126]. Its modern distribution is similar to that of $T$. saileri, but $T$. uhleri is strictly confined to the coastal states, ranging from Quebec in the north to Texas in the south [18, Texas record, http://bugguide.net/node/view/649297].

It is a new state record. Though a Louisiana locality of T. uhleri is situated within the known species range, this finding is worth noting, because the Texas record, most western among the Gulf States, is based on one image of the species in the BugGuide database.

(11) Tytthus vagus (Knight, 1923)

Relative abundance: 49 specimens (in LSAM).
Collection dates: 11 January-1 September.

Hosts: predaceous bug is specialized in its dietary habits, feeding primarily on the eggs and young nymphs of Delphacidae and Cicadellidae [140]. It is considered to be one of the most effective predators for delphacid Prokelisia dolus [141] and can kill up to 24 planthopper eggs per day [142].

Habitat: in coastal communities it has been recorded from Spartina alterniflora and S. bakeri Merr. [143].

Regional distribution: the species was described from the Long Island, New York [139], and is distributed across Atlantic and Gulf States from Newfoundland southward to Louisiana [143].

\section{Discussion}

The assemblage of the dominant and subdominant species in the examined material was represented by seven species, namely, leafhopper Amplicephalus littoralis (Ball) from Cicadellidae, planthoppers Prokelisia dolus Wilson, $P$. marginata (Van Duzee), and Spartidelphax detectus (Van Duzee) (all from Delphacidae), heteropterans Ischnodemus conicus Van Duzee from Blissidae, Trigonotylus uhleri (Reuter), and Tr. saileri Carvalho (both from Miridae). A group of the dominant species with the abundance over 1000 collected specimens was composed of four multivoltine species. Three multivoltine planthoppers $P$. dolus, $P$. marginata, and $S$. detectus comprised $91.9 \%$ of all collected adults of Auchenorrhyncha, and one multivoltine plant bug T. uhleri comprised $93.8 \%$ of all collected heteropterans. All species from the dominant and subdominant groups belonged to sucking herbivores associated with the salt marsh ecosystem with the dominant plants of the family Poaceae (Monocotyledones), either with cordgrass (Spartina alterniflora and/or S. patens) or with seashore saltgrass (Distichlis spicata) (Figure 1, green). In a biogeographical aspect, all species from the dominant and subdominant groups have similar geographical distribution and are native to the Atlantic and Gulf Coast States (Figure 2, dark blue).

The group of common species comprised 11 species, sucking herbivores as well as predators (Figure 1, red). The predators were represented by three species, two minute pirate bugs Orius insidiosus and O. pumilio from Anthocoridae, and one plant bug Tythus vagus from Miridae, that altogether comprised $42.5 \%$ of all specimens of this group. Relatively high abundance of these predators, their small size, and wellknown specialization of T. vagus in egg-feeding [140] suggests that this complex of species feed on eggs and preimaginal stages of the species from the dominant and subdominant groups. Sucking herbivores of the group of common species included not only taxa associated with the dominant coastal plants, but also taxa with wider host preferences. So, the host pattern of the group was characterized by two fractions of polyphagous species and grass generalists absent from the dominant and subdominant groups. As is shown in Figure 1 (dark blue and grey), the fraction of polyphagous species encompassed $37.5 \%$, and the fraction of grass generalists encompassed $25.0 \%$ of all herbivore species of the group. 


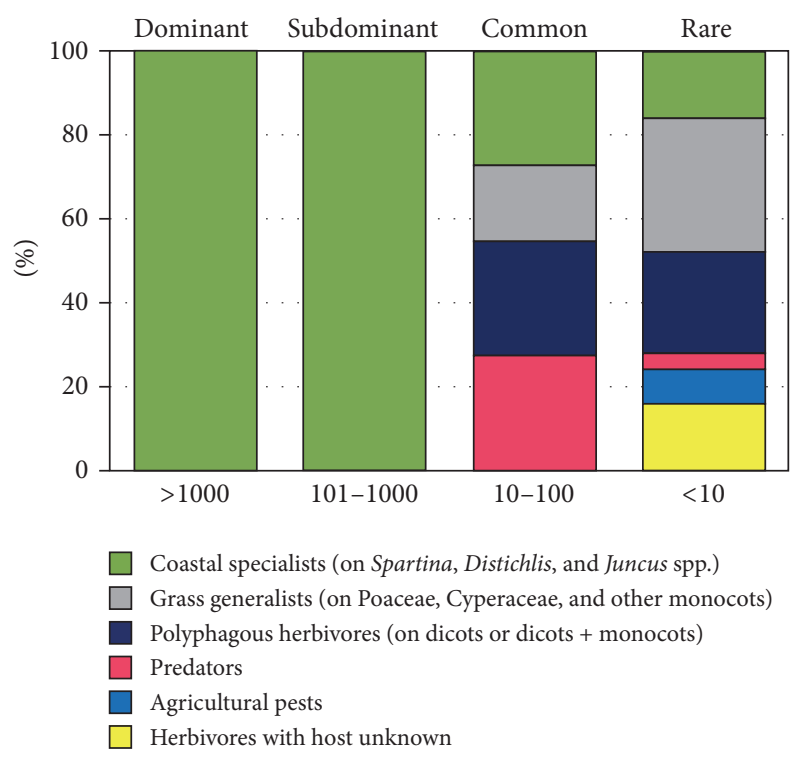

FIGURE 1: Stacked bar chart showing the host-abundance pattern of the members of Auchenorrhyncha and Heteroptera, collected in Louisiana salt marshes in the Mississippi Delta. $X$-axis represents classes of abundance with corresponding species group names and a number of collected specimens per species. Comments in the text.

The range pattern of the group of common species was also different from that of the dominant and subdominant groups. Here, the portion of the Atlantic and Gulf Coasts species started to decline and was replaced by species with different, often wide, and noncoastal types of ranges. It can be seen from the increased proportions of (1) the noncoastal species with either eastern, midwestern, or transcontinental distributions, and of (2) the southern coastal species, distributed in the USA along the Gulf Coast only and absent from the Atlantic Coast States (Figure 2, green and yellow, and light blue and red, resp.). The assemblage of southern coastal species was comprised mostly of the taxa with wide ranges, with either Caribbean or Neotropical distributions, but included also a couple of endemics (Figure 2, red), such as leafhopper Draeculacephala floridana, restricted to the Gulf States, and planthopper Megamelus longicornis, inhabiting the western Gulf States only.

From a total of 44 species, the group representing rare species embraced 25 species and contributed to shaping biodiversity of the examined material. In general, host and range patterns of the group were structurally similar to those of the group of common species but varied in details. Proportion of predators in the group of rare species was close to zero (just one species); thus nearly all diversity of the group was shaped by sucking herbivore species. Host pattern of the herbivores of common and rare species showed similar proportion of the polyphagous species (33-37\%) and of the species associated with grasses $(\sim 50 \%$ of all herbivore species). However, within the latter assemblage the fraction of rare species associated with dominant plants of the salt marsh was noticeably smaller, and, respectively, grass generalists among rare species had a much greater presence

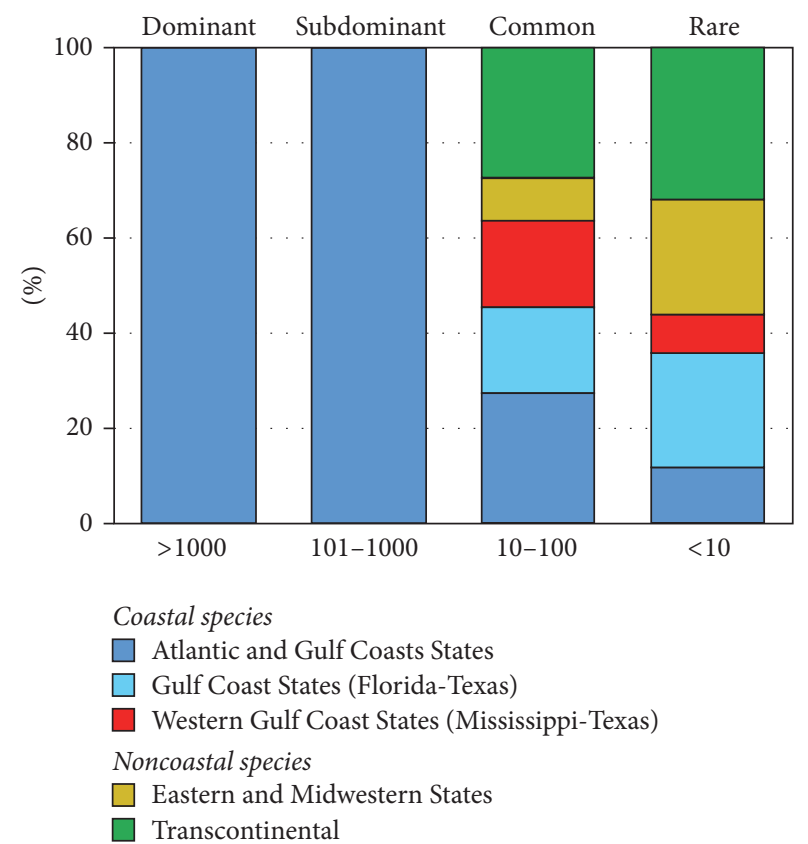

FIGURE 2: Stacked bar chart showing the range-abundance pattern of the members of Auchenorrhyncha and Heteroptera, collected in Louisiana salt marshes in the Mississippi Delta. $X$-axis represents classes of abundance with corresponding species group names and a number of collected specimens per species. Comments in the text.

(Figure 1, green versus grey) in comparison to the group of common species. It is worth mentioning that more than $50 \%$ of collected taxa of the rare species were represented by singletons, and many of these belonged to the species with unknown biology and with unknown hosts (Figure 1, yellow). A certain portion of species collected as singletons definitely belonged to adventive species, accidentally delivered to the salt marsh by wind or otherwise. Presumably, wind transportation was responsible for delivering to the salt marsh a small group of species potentially connected with regional agroindustry (Figure 1, blue). In this group, we place two pests of sugarcane, Perkinsiella saccharicida and Saccharosydne saccharivora, and citrus flatid planthopper Metcalfa pruinosa. The range patterns of the rare species were characterized by the dominance of noncoastal species ( $>50 \%$ of all taxa) with prevalence of taxa with the eastern-midwestern distributions (Figure 2, yellow). Among rare coastal species the fraction of taxa with Gulf Coast States distribution (Figure 2, light blue) similar to the common species was mostly represented by taxa with Neotropical or Caribbean distributions. Only few rare coastal species were represented by local endemics (Figure 2, red): leafhopper Sanctanus fusconotatus from this group is known from the coastal Louisiana only $[33,93]$.

Examined material allowed us to establish new state records for 10 species from which eight are native to the coastal salt marshes of Atlantic and Gulf Coast States. Five of newly recorded species are of Neotropical or Caribbean origin, which may reflect the last years' tendency of the expansion of many species in northward direction possibly due to climate change $[144,145]$. 


\section{Conclusions}

Summarizing the analyzed patterns of Auchenorrhyncha and Heteroptera coastal faunas, it can be stated that within Louisiana salt marsh the core assemblage of species is limited in number and consists of four sap-sucking species, which are tropically connected to the dominant plant of the marsh, Spartina alterniflora. All four are characterized by multivoltine biology and are widely distributed across the Atlantic and Gulf Coasts States. These features reflect successful adaptations of these species to the life in the coastal salt marsh ecosystem and allow them to reach very high densities. However, an actual biodiversity of the sampled material was provided by species with much lower densities, different biology, and biogeography. Among those, one can meet adventive and native coastal species, polyphages and grass specialists, cosmopolitan species, as well as local endemics.

In general, Louisiana salt marshes harbor the same assemblage of dominant species as salt marshes of New Jersey [49], North Carolina [125], South Carolina [146], Florida [147], Alabama [148], and Mississippi [59]. Conversely, the complex of species, belonging to the classes with lower abundancy, differs from other regions. For instance, according to our survey, neighboring Mississippi which possesses the most thoroughly completed checklist of the coastal fauna, has only 13 species of Auchenorrhyncha and six species of Heteroptera in common with Louisiana (cf. Lago and Testa III in [59]). The most striking feature of the examined material is the lack of planthoppers Spartidelphax penedetectus (Beamer) and representatives of Tumidagena, characteristic elements of the salt marsh fauna of the Atlantic Coast [19, 25, 149151]. The future investigations will show whether the recorded difference in hemipteran fauna between Louisiana and other regions is an artifact or points to unknown natural reasons. Nevertheless, for some groups of taxa the difference in faunistic lists can be explained by the following causes. Partly, it may be connected with the differences in collecting techniques: Louisiana material was obtained by sweep-net method only, while other researchers used light traps, Malaise traps, pitfalls, sticky plates, or hand picking in addition to netsweeping techniques (cf. methods in $[59,146,148]$ ). For some genera, the incongruity is linked to the problems in recognizing species of taxonomically difficult groups (e.g., Balclutha), taxa of which in previous studies were not identified to the species level. Finally, natural and unpredictable fluctuations in the number of occasional and adventive species may also be a cause of certain deviations in faunistic lists of the community.

\section{Conflicts of Interest}

There are no conflicts of interest regarding this paper.

\section{Acknowledgments}

The authors thank Mark Acardo, Brooke Hesson, Carson McCord, Onyinye Ossisioma, Stephen Patin, Brian Reily, Ryan Roy, Gerald Soderstrom, Alexander Sabo, and Elliott Thompson for their help sorting and organizing the material.
Benjamin "Max" Adams, M. Acardo, B. Hesson, A. Sabo, and G. Soderstrom are thanked for their help in collecting the specimens. The authors are also very thankful to D. Dmitriev and C. Dietrich (INHS, Champaign, IL) for confirming identification of Auchenorrhyncha species (except Delphacidae). This research was made possible by a grant to LMHB via the Coastal Waters Consortium from The Gulf of Mexico Research Initiative. Data are publicly available through the Gulf of Mexico Research Initiative Information \& Data Cooperative (GRIIDC) at https://data.gulfresearchinitiative.org (doi: $<10.7266 / \mathrm{N} 7 \mathrm{~W} 37 \mathrm{TSD}>$ ).

\section{References}

[1] J. Barras, S. Beville, D. Britsch et al., "Historical and projected coastal Louisiana land changes," 2003, U.S. Geological Survey Open File Report 03-334, 39 pp.

[2] S. Penland, P. F. Connor Jr., A. Beall, S. Fearnley, and S. J. Williams, "Changes in Louisiana's shoreline: 1855-2002," Journal of Coastal Research, vol. 21, no. 44, pp. 7-39, 2005.

[3] B. R. Silliman, J. Van De Koppel, M. W. McCoy et al., "Degradation and resilience in Louisiana salt marshes after the BP-Deepwater Horizon oil spill," Proceedings of the National Acadamy of Sciences of the United States of America, vol. 109, no. 28, pp. 11234-11239, 2012.

[4] D. J. Reed and L. Wilson, "Coast 2050: a new approach to restoration of louisiana coastal wetlands," Physical Geography, vol. 25, no. 1, pp. 4-21, 2004.

[5] L. J. Moore, K. Patsch, J. H. List, and S. J. Williams, "The potential for sea-level-rise-induced barrier island loss: Insights from the Chandeleur Islands, Louisiana, USA," Marine Geology, vol. 355, pp. 244-259, 2014.

[6] C. Kremen, A. M. Merenlender, and D. D. Murphy, "Ecological monitoring: a vital need for integrated conservation and development programs in the tropics," Conservation Biology, vol. 8, no. 2, pp. 388-397, 1994.

[7] Y. Basset, O. Missa, A. Alonso et al., "Choice of metrics for studying arthropod responses to habitat disturbance: one example from Gabon," Insect Conservation and Diversity, vol. 1, no. 1, pp. 55-66, 2008.

[8] M. W. LaSalle and T. Dale Bishop, "Seasonal abundance of aquatic diptera in two oligohaline tidal marshes in Mississippi," Estuaries and Coasts, vol. 10, no. 4, pp. 303-315, 1987.

[9] S. C. Pennings, B. D. McCall, and L. Hooper-Bui, "Effects of oil spills on terrestrial arthropods in coastal wetlands," Bioscience, vol. 64, no. 9, pp. 789-795, 2014.

[10] J. M. Coleman, H. H. Roberts, and G. W. Stone, "Mississippi River delta: an overview," Journal of Coastal Research, vol. 14, no. 3, pp. 698-716, 1998.

[11] C. A. Wilson and M. A. Allison, "An equilibrium profile model for retreating marsh shorelines in southeast Louisiana," Estuarine, Coastal and Shelf Science, vol. 80, no. 4, pp. 483-494, 2008.

[12] C. E. Sasser, J. M. Visser, E. Mouton, J. Linscombe, and S. B. Hartley, "Vegetation types in Coastal Louisiana in 2013. U.S. Geological Survey Scientific Investigations Map 3290, 1 Sheet, Scale 1:550,000, United States GeologicalSurvey: Lafayette, LA, USA," 2014.

[13] C. R. Bartlett, L. B. O'Brien, and S. W. Wilson, "A review of the planthoppers (Hemiptera: Fulgoroidea) of the United States," 
Memoirs of the American Entomological Society, vol. 50, pp. 1287, 2014.

[14] C. H. Dietrich, "Keys to the families of Cicadomorpha and subfamilies and tribes of Cicadellidae (Hemiptera: Auchenorrhyncha)," Florida Entomologist, vol. 88, no. 4, pp. 502-517, 2005.

[15] D. M. DeLong, "The leafhoppers, or Cicadellidae, of Illinois (Eurymelinae-Balcluthinae)," Bulletin of the Illoinois Natural History Survey, vol. 24, no. 2, pp. 97-376, 1948.

[16] W. S. Blatchley, Heteroptera, Or True Bugs of Eastern North America, with Especial Reference to The Faunas of Indiana And Florida, The Nature Publishing Co., Indianapolis, IN, USA, 1926.

[17] R. H. Beamer, "A revision of the genus Megamelus in America North of Mexico (Homoptera, Fulgoridae, Delphacinae)," Journal of the Kansas Entomological Society, vol. 28, pp. 29-40, 1955.

[18] L. D. Kelton, "Revision of the species of Trigonotylus in north America (heteroptera: miridae)," The Canadian Entomologist, vol. 103, no. 5, pp. 685-705, 1971.

[19] C. R. Bartlett and M. D. Webb, "The planthopper genus Spartidelphax, a new segregate of Nearctic Delphacodes (Hemiptera, Delphacidae)," ZooKeys, no. 453, pp. 19-36, 2014.

[20] J. A. Slater and R. M. Baranowski, The Lygaeidae of Florida (Hemiptera: Lygaeidae). Arthropods of Florida and Neighboring Land Areas, vol. 14, Florida Department of Agriculture and Consumer Services, Division of Plant Industry, Gainesville, FL, USA, 1990.

[21] L. M. Hernández and T. J. Henry, The plant bugs, or Miridae (Hemiptera: Heteroptera), of Cuba, Pensoft Series Faunistica, Moscow, Russia, 2010.

[22] R. F. Denno, G. K. Roderick, K. L. Olmstead, and H. G. Dobel, "Density-related migration in planthoppers (Homoptera: Delphacidae): the role of habitat persistence," The American Naturalist, vol. 138, no. 6, pp. 1513-1541, 1991.

[23] R. H. Beamer, "Five new genera of delphacine fulgorids (Homoptera-Fulgoridae-Delphacinae)," Journal of the Kansas Entomological Society, vol. 23, pp. 128-133, 1950.

[24] C. R. Bartlett et al., "Delphacid planthoppers of North America," 2014, http://ag.udel.edu/enwc/research/delphacid/index.html.

[25] S. W. Wilson, "Tymbal morphology and co-occurrence of spartina sap-feeding insects (Hemiptera: Auchenorrhyncha)," Great Lakes Entomologist, vol. 45, no. 3-4, pp. 164-182, 2012.

[26] H. L. Dozier, "A synopsis of the genus Stenocranus, and a new species of Mysidia (Homoptera)," The Ohio Journal of Science, Columbus, vol. 22, pp. 69-82, 1922.

[27] F. X. Fieber, "Grundzüge zur generischen Theilung der Delphacini," Verhandlungen der Kaiserlich-Königlichen Zoologishbotanischen Gesellschaft in Wien, vol. 16, pp. 517-534, 1866.

[28] A. T. Gonzon and C. R. Bartlett, "Systematics of Hadropygos n.g., Metadelphax Wagner and New World Toya Distant (Hemiptera: Delphacidae)," Transactions of the American Entomological Society, vol. 133, no. 3-4, pp. 205-277, 2007.

[29] S. W. Wilson, "Keys to the families of fulgoromorpha with emphasis on planthoppers of potential economic importance in the southeastern united states (Hemiptera: Auchenorrhyncha)," Florida Entomologist, vol. 88, no. 4, pp. 464-481, 2005.

[30] E. D. Ball, "Some new Homoptera from the south and southwest," Proceedings of the Biological Society of Washington, vol. 18, no. 06, pp. 117-120, 1905.

[31] E. D. McCoy and J. R. Rey, "Patterns of abundance, distribution, and alary polymorphism among the salt marsh Delphacidae
(Homoptera: Fulgoroidea) of Northwest Florida," Ecological Entomology, vol. 6, no. 3, pp. 285-291, 1981.

[32] H. Osborn, "Descriptions of new North American Fulgoridae," The Ohio Naturalist, Columbus, vol. 5, pp. 373-376, 1905.

[33] D. A. Dmitriev, "World Auchenorrhyncha database," 2004, http://dmitriev.speciesfile.org.

[34] G. W. Kirkaldy, "Miscellanea rhynchotalia," The Entomologist, vol. 36, no. 7, pp. 179-181, 1903.

[35] O. Sosa Jr, "The sugarcane delphacid, Perkinsiella saccharicida (Homoptera: Delphacidae), a sugarcane pest new to North America detected in Florida," Florida Entomologist, vol. 68, no. 2, pp. 357-360, 1985.

[36] W. H. White, T. E. Reagan, and O. Sosa Jr, “The sugarcane delphacid (Homoptera: Delphacidae) extends its North American range into Louisiana," Florida Entomologist, vol. 78, no. 4, pp. 617-619, 1995.

[37] K. Dhileepan, B. J. Croft, A. W. Ridley, A. P. James, and S. Raghu, "Susceptibility of source plants to Sugarcane Fiji disease virus influences the acquisition and transmission of the virus by the planthopper vector Perkinsiella saccharicida," Journal of Applied Entomology, vol. 130, no. 1, pp. 67-71, 2006.

[38] E. P. Van Duzee, "A preliminary review of the North American Delphacidae," Bulletin of the Buffalo Society of Natural Sciences, vol. 5, pp. 225-261, 1897.

[39] M. D. Holder and S. W. Wilson, "Life history of the delphacid planthopper Prokelisia crocea (Homop-tera: Fulgoroidea)," Journal of the New York Entomological Society, vol. 100, pp. 491-497, 1992.

[40] S. W. Wilson, "The planthopper genus Prokelisia in the United States (Homoptera: Fulgoroidea: Delphacidae)," Journal of the Kansas Entomological Society, vol. 55, pp. 532-546, 1982.

[41] R. F. Denno, M. A. Peterson, C. Gratton et al., "Feeding-induced changes in plant quality mediate interspecific competition between sap-feeding herbivores," Ecology, vol. 81, no. 7, pp. 1814$1827,2000$.

[42] D. Ouvrard and A. Soulier-Perkins, "Prokelisia marginata (Van Duzee, 1897) lands on the French coast of Normandy (Hemiptera, Fulgoromorpha, Delphacidae)," Bulletin de la Société Entomologique de France, vol. 117, pp. 441-444, 2012.

[43] M.-Y. Wu, S. Hacker, D. Ayres, and D. R. Strong, "Potential of Prokelisia spp. as biological control agents of English Cordgrass, Spartina anglica," Biological Control, vol. 16, no. 3, pp. 267-273, 1999.

[44] M. D. Eubanks, M. J. Raupp, and D. L. Finke, "Robert F. Denno (1945-2008): insect ecologist extraordinaire," Annual Review of Entomology, vol. 56, pp. 273-292, 2011.

[45] R. G. Fennah, "The Delphacid-species-complex known as Sogatella furcifera (Horvath) (Homoptera: Fulgoroidea)," Bulletin of Entomological Research, vol. 54, no. 1, pp. 45-79, 1963.

[46] E. Ammar, "Biology of the planthopper Sogatella vibix (Haupt) in Giza, Egypt (Hom., Delphacidae)," Deutsche Entomologische Zeitschrift, vol. 24, no. 1-3, pp. 151-158, 1977.

[47] J. K. Ballou, J. H. Tsai, and S. W. Wilson, "Delphacid planthoppers Sogatella kolophon and Delphacodes idonea (Homoptera: Delphacidae): descriptions of immature stages and notes on biology," Annals of the Entomological Society of America, vol. 80, no. 2, pp. 312-319, 1987.

[48] K. K. M. Myint, H. Yasui, M. Takagi, and M. Matsumura, "Virulence of long-term laboratory populations of the brown 
planthopper, Nilaparvata lugens (Stål), and whitebacked planthopper, Sogatella furcifera (Horvath) (Homoptera: Delphacidae), on rice differential varieties," Applied Entomology and Zoology, vol. 44, no. 1, pp. 149-153, 2009.

[49] R. F. Denno, "Comparison of the assemblages of sap-feeding insects (Homoptera-Hemiptera) inhabiting two structurally different salt marsh grasses in the genus Spartina," Environmental Entomology, vol. 6, no. 3, pp. 359-372, 1977.

[50] J. O. Westwood, "Additional observations upon the insect which infests the sugar canes in Grenada," The Magazine of Natural History and Journal of Zoology, Botany, Mineralogy, Geology, and Meteorology, vol. 6, pp. 409-413, 1833.

[51] J. R. Metcalfe, "Studies on the biology of the sugar cane pest Saccharosydne saccharivora (Westw.) (Hom.: Delphacidae)," Bulletin of Entomological Research, vol. 59, no. 3, pp. 393-408, 1969.

[52] J. R. Metcalfe, "Observations on the ecology of Saccharosydne saccharivora (Westw.) (Hom., Delphacidae) in Jamaican sugarcane fields," Bulletin of Entomological Research, vol. 60, no. 4, pp. 565-597, 1971.

[53] Y. Arocha, M. López, M. Fernández et al., "Transmission of a sugarcane yellow leaf phytoplasma by the delphacid planthopper Saccharosydne saccharivora, a new vector of sugarcane yellow leaf syndrome," Plant Pathology, vol. 54, no. 5, pp. 634642, 2005.

[54] Z. P. Metcalf, "A key to the Fulgoridae of Eastern North America with descriptions of new species," Journal of the Elisha Mitchell Scientific Society, vol. 38, pp. 139-230, 1923.

[55] S. W. Wilson and A. G. Wheeler Jr, "Planthopper (Hemiptera: Fulgoroidea) diversity of weeping lovegrass (Eragrostis curvula), an introduced host of little-known, rarely collected native species," Entomologica Americana, vol. 116, no. 3-4, pp. 98-106, 2010.

[56] T. Say, "Descriptions of new north American Hemipterous insects, belonging to the first family of the section Homoptera of Latreille," Journal of the Academy of Natural Sciences of Philadelphia, vol. 6, pp. 235-244, 1830.

[57] F. W. Mead, Citrus flatid planthopper, Metcalfa pruinosa (Say) Homoptera: Flatidae, Entomology Circular No. 85, Florida Department of Agriculture, Division of Plant Industry, 1969.

[58] S. W. Wilson and J. E. McPherson, "A list of host plants of the Illinois Acanaloniidae and Flatidae (Homoptera: Fulgoroidea)," Transactions of the Illinois State Academy of Science, vol. 73, pp. 21-29, 1980.

[59] P. K. Lago and S. Testa, "The terrestrial Hemiptera and auchenorrhynchous homoptera of point clear island and surrounding marshlands, hancock county," Journal of the Mississippi Academy of Sciences, vol. 45, pp. 184-193, 2000.

[60] P. W. Oman, A Classification of North American Agallian Leaf Hoppers, vol. 372, U.S. Department of Agriculture Technical Bulletin, 1933.

[61] P. H. Freytag, "Corrections and additions to the genus Agallia (Homoptera, Cicadellidae, Agalliinae) of the Americas," Entomological News, vol. 114, no. 4, pp. 181-186, 2003.

[62] K. G. A. Hamilton and R. F. Whitcomb, "Leafhoppers (Homoptera: Cicadellidae), a major family adapted to grassland habitats," in Arthropods of Canadian Grasslands, 1: Ecology and Interactions in Grassland Habitats, J. D. Shorthouse, Ed., Biological Survey of Canada Monograph Series No. 3, chapter 8, pp. 169-197, 2010.

[63] P. R. Lowry, “Cicadellidae leafhoppers of New Hampshire," Ohio Journal of Science, vol. 33, pp. 59-80, 1933.
[64] P. M. Ferrari, "Cicadaria Agri Ligustici," Annali Del Museo Civico Di Storia Naturale Di Genova, vol. 18, pp. 75-165, 1882.

[65] W. J. Knight, "Leafhoppers of the grass-feeding genus Balclutha (Homoptera, Cicadellidae) in the Pacific region," Journal of Natural History, vol. 21, no. 5, pp. 1173-1224, 1987.

[66] R. H. Davidson and D. M. DeLong, "A review of the North American species of Balclutha and Agellus (Homoptera: Cicadellidae)," Proceedings of the Entomological Society of Washington, vol. 37, pp. 97-112, 1935.

[67] R. L. Meagher Jr, S. W. Wilson, H. D. Blocker, R. V. W. Eckel, and R. S. Pfannenstiel, "Homoptera associated with sugarcane fields in Texas," The Florida Entomologist, vol. 76, no. 3, pp. 508-514, 1993.

[68] A. M. Rossi and D. R. Strong, "Natural history of the leafhopper Carneocephala floridana (Homoptera: Cicadellidae) in a north Florida salt marsh," The Florida Entomologist, vol. 73, no. 1, pp. 147-153, 1990.

[69] E. D. Ball, "A review of the Tettigonidae of North America north of Mexico," Proceedings of the Iowa Academy of Science, vol. 8 , pp. 35-75, 1900.

[70] C. H. Dietrich, "Systematics of the leafhopper genus Draeculacephala Ball (Homoptera: Cicadellidae)," Transactions of the American Entomological Society, vol. 120, pp. 87-112, 1994.

[71] E. D. Ball, "The genus Draeculacephala and its allies in North America (Rhynchota Homoptera)," The Florida Entomologist, vol. 11, pp. 33-40, 1927.

[72] D. A. Young Jr and R. H. Davidson, "A review of leafhoppers of the genus Draeculacephala," U.S. Department of Agriculture Technical Bulletin, vol. 1198, pp. 1-32, 1959.

[73] K. G. A. Hamilton, "Review of DraeculacephalaBall (Homoptera, Auchenorrhyncha, Cicadellidae)," Entomologische Abhandlungen. Staatliches Museum für Tierkunde, Dresden, vol. 49, pp. 83-103, 1985.

[74] D. M. DeLong, "A revision of the American species of Empoasca known to occur north of Mexico," U.S. Department of Agriculture Technical Bulletin, vol. 231, pp. 1-59, 1931.

[75] H. R. Moffitt and H. T. Reynolds, "Bionomics of Empoasca solana DeLong on cotton in southern California," Hilgardia, vol. 41, pp. 247-298, 1972.

[76] H. H. Ross, G. C. Decker, and H. B. Cunningham, "Adaptation and differentiation of temperate phylogenetic lines from tropical ancestors in Empoasca," Evolution, vol. 18, no. 4, pp. 639-651, 1965.

[77] P. R. Uhler, "Remarks on a new form of jassid," American Entomologist, vol. 3, pp. 72-73, 1880.

[78] R. D. Gustin and W. N. Stoner, "Life history of Exitianus exitiosus (Homoptera: Cicadellidae) in the laboratory," Annals of the Entomological Society of America, vol. 66, no. 2, pp. 388389, 1973.

[79] D. M. DeLong and R. V. Hershberger, "The genus Exitianus in North America including Mexico (Homoptera: Cicadellidae)," Ohio Journal of Science, vol. 47, pp. 107-116, 1947.

[80] S. A. Forbes, Report of the State Entomologist on the noxious and beneficial insects of the State of Illinois, Report of the State Entomologist, Illinois, , IL, USA, 14th edition, 1885.

[81] F. J. Boyd and H. N. Pitre, "Greenhouse studies of host plant suitability to Graminella nigrifrons, a vector of corn stunt virus," Journal of Economic Entomology, vol. 62, no. 1, pp. 126-130, 1969.

[82] W. N. Stoner and R. D. Gustin, "Biology of Graminella nigrifrons (Homoptera-Cicadellidae) a vector of corn (maize) stunt virus," 
Annals of the Entomological Society of America, vol. 60, no. 3, pp. 496-505, 1967.

[83] M. R. Wilson and J. A. Turner, Leafhopper, Planthopper and Psyllid Vectors of Plant Disease, Amgueddfa Cymru-National Museum Wales, 2010, http://naturalhistory.museumwales.ac .uk/Vectors/.

[84] E. D. Ball, "Some new jassidæ from the southwest," The Canadian Entomologist, vol. 32, no. 7, pp. 200-205, 1900.

[85] R. Creamer, X. He, and W. E. Styer, “Transmission of sorghum stunt mosaic rhabdovirus by the leafhopper vector, Graminella sonora (Homoptera: Cicadellidae)," Plant Disease, vol. 81, no. 1, pp. 63-65, 1997.

[86] G. D. Buntin, "Species composition and phenology of leafhoppers (Homoptera: Cicadellidae) and planthoppers (Homoptera: Delphacidae) in bermudagrass forage," Journal of Economic Entomology, vol. 81, no. 1, pp. 201-207, 1988.

[87] D. M. DeLong, "A monographic study of the North American species of the genus Deltocephalus. University Studies," The Ohio State University. Contributions in Zoology and Entomology, vol. 2, no. 13, pp. 1-129, 1926.

[88] C. Stål, "Hemiptera mexicana enumeravit speciesque novas descripsit. (Continuatio)," Entomologische Zeitung. Herausgegeben von dem entomologischen Vereine zu Stettin. Stettin, vol. 25, pp. 49-86, 1864.

[89] E. D. Ball, "A review of the species of the genus Gypona occurring in North America, north of Mexico (Homoptera)," Annals of the Entomological Society of America, vol. 13, no. 1, pp. 83-100, 1920.

[90] H. Osborn, "New species of Cicadellidae from the southern U.S. (Homoptera)," The Florida Entomologist, vol. 6, pp. 17-20, 1922.

[91] R. F. Denno, "Tracking variable host plants in space and time," in Variable Plants and Herbivores in Natural and Managed Systems, R. F. Denno and M. S. McClure, Eds., pp. 291-341, Academic Press, New York, NY, USA, 1983.

[92] S. C. Phatak, M. B. Callaway, and C. S. Vavrina, "Biological control and its integration in weed management systems for purple and yellow nutsedge (Cyperus rotundus and C. esculentus)," Weed Science, vol. 1, pp. 84-91, 1987.

[93] D. M. Delong and R. Y. Hershberger, "The genus Sanctanus in North America including the mexican species," Annals of the Entomological Society of America, vol. 39, no. 2, pp. 207-224, 1946.

[94] P. R. Uhler, "Report upon the insects collected by P. R. Uhler during the explorations of 1875, including monographs of the families Cydnidae and Saldae and the Hemiptera collected by A. S. Packard, Jr., M. D. Bulletin of the United States Geological and Geographical Survey of the Territories, Washington, 3: 355$475, " 1877$.

[95] J. H. Tsai and J. B. Fisher, "Feeding sites of some leaf- and planthopper insects (Homoptera: Auchenorrhyncha) associated with coconut palms," Principes, vol. 37, pp. 35-41, 1993.

[96] N. Ma, "A review of the genus Spangbergiella (Homoptera: Cicadellidae: Deltocephalinae)," Journal of the Kansas Entomological Society, vol. 61, pp. 363-369, 1998.

[97] V. Signoret, "Revue iconographique des Tettigonides," Annales de la Societe Entomologique de France, vol. 2, pp. 5-28, 1854.

[98] T. A. Catanach, C. H. Dietrich, and J. B. Woolley, "A revision of the New World sharpshooter genus XyphonHamilton (Hemiptera: Cicadellidae: Cicadellinae)," Zootaxa, vol. 3741, no. 4, pp. 490-510, 2013.
[99] K. G. A. Hamilton, The spittlebugs of Canada (Homoptera: Cercopidae), Insects and Arachnids of Canada, part 10, Biosystematics Research Institute, Ottawa, Ontario, Canada, 1982.

[100] E. D. Ball, “The genus Clastoptera (Cercopidae)," The Canadian Entomologist, vol. 59, no. 5, pp. 103-112, 1927.

[101] E. F. Germar, "Drei neue Gattungen der Cicadinen, aufgestellt vom herausgeber. Zeitschrift für die Entomologie, herausgegeben von E. F. Germar," Leipzig, vol. 1, pp. 187-192, 1839.

[102] A. Soulier-Perkins, "COOL_Cercopoidea Organised On Line," 2017, http://hemiptera-databases.org/cool/.

[103] C. H. Dietrich, M. J. Rothschild, and L. L. Deitz, "Checklist and host plants of the treehoppers (Hemiptera: Membracidae) of North Carolina," Proceedings of the Entomological Society of Washington, vol. 101, no. 2, pp. 242-262, 1999.

[104] L. L. Deitz and M. S. Wallace, "Richness of the nearctic treehopper fauna (Hemiptera: Aetalionidae and Membracidae)," Zootaxa, no. 3423, pp. 1-26, 2012.

[105] D. J. Flynn, "Checklist of treehoppers of Panama (Hemiptera: Membracidae) with a list of checklists and keys to the Nearctic and Neotropical fauna," Zootaxa, no. 3405, pp. 35-63, 2012.

[106] T. Say, "Description of new species of heteropterous Hemiptera of North America. New Harmony, Indiana, 1-39," 1832.

[107] X. Xu, C. Borgemeister, and H.-M. Poehling, "Interactions in the biological control of western flower thrips Frankliniella occidentalis (Pergande) and the two-spotted spider mite Tetranychus urticae Koch by the predatory bug Orius insidiosus Say on beans," Biological Control, vol. 36, no. 1, pp. 57-64, 2006.

[108] I. Baez, S. R. Reitz, and J. E. Funderburk, "Predation by Orius insidiosus(Heteroptera: Anthocoridae) on life stages and species of Frankliniellaflower thrips (Thysanoptera: Thripidae) in pepper flowers," Environmental Entomology, vol. 33, no. 3, pp. 662-670, 2004.

[109] C. E. Rutledge and R. J. O’Neil, "Orius in sidiosus (Say) as a predator of the soybean aphid, Aphis glycines Matsumura," Biological Control, vol. 33, no. 1, pp. 56-64, 2005.

[110] J. Funderburk, "Management of the western flower thrips (thysanoptera: Thripidae) in fruiting vegetables," Florida Entomologist, vol. 92, no. 1, pp. 1-6, 2009.

[111] J. Funderburk, J. Stavisky, and S. Olson, "Predation of Frankliniella occidentalis (Thysanoptera: Thripidae) in field peppers by Orius insidiosus (Hemiptera: Anthocoridae)," Environmental Entomology, vol. 29, no. 2, pp. 376-382, 2000.

[112] J. L. Herring, "The genus Orius of the Western Hemisphere (Hemiptera: Anthocoridae)," Annals of the Entomological Society of America, vol. 59, no. 6, pp. 1093-1109, 1966.

[113] L. A. Kelton, "Synopsis of the genus Orius Wolff in America north of Mexico (Heteroptera: Anthocoridae)," The Canadian Entomologist, vol. 95, no. 6, pp. 631-636, 1963.

[114] J. M. Schmidt, P. C. Richards, H. Nadel, and G. Ferguson, "A rearing method for the production of the large numbers of the Insidiosus Flower Bug, Orius insidiosus (Say) (Hemiptera: Anthocoridae)," The Canadian Entomologist, vol. 127, no. 3, pp. 445-447, 1995.

[115] D. Sprague and J. Funderburk, "nsidiosus flower bug, Minute Pirate Bug Orius insidiosus Say (Insecta: Hemiptera: Anthocoridae)," Tech. Rep. EENY-665, Department of Entomology and Nematology, University of Florida, Institute of Food and Agricultural Sciences Extension, 2016.

[116] G. C. Champion, "Anthocoridae. Insecta. Rhynchota. Hemiptera-Heteroptera," in Biologia Centrali-Americana, 
F. D. Godman and O. Salvin, Eds., vol. 2 of 336, p. 306, Taylor and Francis, London, UK, 1900.

[117] J. M. G. Thomas, P. D. Shirk, and J. P. Shapiro, "Mass rearing of a tropical minute pirate bug, Orius pumilio (Hemiptera: Anthocoridae)," Florida Entomologist, vol. 95, no. 1, pp. 202204, 2012.

[118] J. G. Needham, "Ecological notes on the insect population of the flower heads of Bidens pilosa," Ecological Monographs, vol. 18, no. 3, pp. 431-446, 1948.

[119] J. D. Lattin, "Bionomics of the nabidae," Annual Review of Entomology, vol. 34, pp. 383-400, 1989.

[120] M. L. Boyd and D. J. Boethel, "Susceptibility of predaceous hemipteran species to selected insecticides on soybean in Louisiana," Journal of Economic Entomology, vol. 91, no. 2, pp. 401-409, 1998.

[121] I. M. Kerzhner and T. J. Henry, "Three new species, notes and new records of poorly known species, and an updated checklist for the North American Nabidae (Hemiptera: Heteroptera)," Proceedings of the Entomological Society of Washington, vol. 110, no. 4, pp. 988-1011, 2008.

[122] J. E. Harrington, "Notes on the biology of Ischnodemusspecies of America North of Mexico (Hemiptera: Lygaeidae: Blissinae)," Occasional papers, Biological science series, vol. 2, no. 6, pp. 4756, 1972.

[123] E. P. Van Duzee, "North American Heteroptera," Entomological News, vol. 20, pp. 231-234, 1909.

[124] C. Stål, "Enumeratio Hemipterorum. Bidrag till en förteckning öfver alla hittills könda Hemiptera, jemte sistematiska meddelanden. 4. Kongliga Svenska Vetenskaps-Akademiens Handlingar, n.f., Bd. 12: 1-186," 1873.

[125] L. V. Davis and I. E. Gray, "Zonal and seasonal distribution of insects in North Carolina saltmarshes," Ecological Monographs, vol. 36, no. 3, pp. 276-295, 1966.

[126] O. M. Reuter, "Capsinae ex America boreali in Museo Holmiensi asservatae, descriptae. Öfversigt af Kongliga Svenska Vetenskaps," Akademiens Förhandlingar, vol. 32, pp. 59-92, 1876.

[127] J. Maldonado Capriles, "Concerning Cuban Miridae (Insecta: Hemiptera," Caribbean Journal of Science, vol. 22, pp. 125-136, 1986.

[128] D. Leston, "The species of Dagbertus (Hemiptera: Miridae) associated with avocado in Florida," The Florida Entomologist, vol. 62, no. 4, pp. 376-379, 1979.

[129] G. L. Snodgrass, T. J. Henry, and W. P. Scott, "An annotated list of the Miridae (Heteroptera) found in the Yazoo-Mississippi Delta and associated areas in Arkansas and Louisiana," in Proceedings of the Entomological Society of Washington, vol. 86, pp. 845-860, 1984.

[130] T. J. Henry and A. G. Wheeler Jr, "Family Miridae Hahn, 1833 (=Capsidae Burmeister, 1835). The plants bugs," in Catalog of the Heteroptera, or True Bugs, of Canada and the Continental United Stated, T. J. Henry and A. G. Wheeler Jr, Eds., pp. 1-958, E. J. Brill, New York, NY, USA, 1988.

[131] O. M. Reuter, "Capsidae in Venezuela a D:o D:re Fr. Meinert collectae enumeratae novaeque species descriptae," Öfversikt af Finska Vetenskaps-Societetens Förhandlingar, vol. 47, no. 19, p. 39, 1905.

[132] G. P. Donnelly, "Biology and host specificity of Rhinacloa callicrates Herring (Hemiptera: Miridae) and its introduction and establishement as a biological control agent of Parkinsonia aculeate L. (Caesalpiniaceae) in Australia," Australian Journal of Entomology, vol. 39, no. 2, pp. 89-94, 2000.
[133] R. T. Schuh and M. D. Schwartz, "Revision of the plant bug genus Rhinacloa Reuter with a phylogenetic analysis (Hemiptera: Miridae)," Bulletin of the American Museum of Natural History, vol. 179, pp. 379-470, 1985.

[134] L. E. Vivas, M. Cermeli, and F. Godoy, "rimera cita de Trigonotylus tenuis Reuter, 1893 (Hemiptera: Miridae) causando daños en el cultivo del arroz (Oryza sativa L.) en Venezuela," Entomotropica, vol. 20, pp. 125-126, 2005.

[135] O. M. Reuter, "New species of Miridae," in Mission scientifique de M. Ch. Alluaud aux Iles Sechelles, E. Bergroth, Ed., vol. 12, pp. 197-209, Revue d'Entomologie, Caen, France, 1893.

[136] R. T. Schuh, "On-line Systematic Catalog of Plant Bugs (Insecta: Heteroptera: Miridae)," 2002, http://research.amnh.org/pbi/ catalog/.

[137] J. C. M. Carvalho and E. Wagner, "A world revision of the genus Trigonotylus Fieber (Hemiptera-Heteroptera, Miridae)," Arquivos do Museu Nacional, Rio de Janeiro, vol. 43, pp. 121-155, 1957.

[138] C. C. Daehler and D. R. Strong, "Impact of high herbivore densities on introduced smooth cordgrass, Spartina alterniflora, invading San Francisco Bay, California," Estuaries and Coasts, vol. 18, no. 2, pp. 409-417, 1995.

[139] H. H. Knight, Guide to the insects of Connecticut. Part IV. The Hemiptera or sucking insects of Connecticut-Family Miridae (Capsidae), Bulletin no. 34, State of Connecticut Geological and Natural History Survey, 1923.

[140] H. G. Döbel and R. F. Denno, "Predator-planthopper interactions," in Planthopers: Their Ecology and Management, R. F. Denno and T. J. Perfect, Eds., pp. 325-399, Chapman \& Hall, New York, NY, USA, 1994.

[141] R. F. Denno, D. Lewis, and C. Gratton, "Spatial variation in the relative strength of top-down and bottom-up forces: causes and consequences for phytophagous insect populations," Annales Zoologici Fennici, vol. 42, no. 4, pp. 295-311, 2005.

[142] D. L. Finke and R. F. Denno, "Intraguild predation diminished in complex-structured vegetation: Implications for prey suppression," Ecology, vol. 83, no. 3, pp. 643-652, 2002.

[143] T. J. Henry, "Revision of the plant bug genus Tytthus (Hemiptera, Heteroptera, Miridae, Phylinae)," ZooKeys, vol. 220, pp. 1-114, 2012.

[144] S. J. Melles, M.-J. Fortin, K. Lindsay, and D. Badzinski, "Expanding northward: influence of climate change, forest connectivity, and population processes on a threatened species' range shift," Global Change Biology, vol. 17, no. 1, pp. 17-31, 2011.

[145] S. Gillings, D. E. Balmer, and R. J. Fuller, "Directionality of recent bird distribution shifts and climate change in Great Britain," GCB Bioenergy, vol. 21, no. 6, pp. 2155-2168, 2015.

[146] L. V. Davis, "Class Insecta," in An annotated checklist of the biota of the coastal zone of South Carolina, R. G. Zingmark, Ed., vol. 2, pp. 186-220, Univ. of South Carolina Press, Columbia, 1978.

[147] J. R. Rey and E. D. McCoy, "Terrestrial arthropods of northwest Florida salt marshes: Hemiptera and Homoptera (Insecta)," The Florida Entomologist, vol. 65, no. 2, pp. 241-248, 1982.

[148] E. P. Benton and J. W. McCreadie, "A preliminary survey of the planthoppers (Hemiptera: Fulgoroidea) of Coastal Alabama," Proceedings of the Entomological Society of Washington, vol. 111, no. 2, pp. 354-360, 2009.

[149] R. F. Denno, “The optimum population strategy for planthoppers (homoptera: Delphacidae) in stable marsh habitats," The Canadian Entomologist, vol. 110, no. 2, pp. 135-142, 1978. 
[150] R. F. Denno, C. Gratton, H. Döbel, and D. L. Finke, "Predation risk affects relative strength of top-down and bottom-up impacts on insect herbivores," Ecology, vol. 84, no. 4, pp. 10321044, 2003.

[151] A. C. Kennedy, C. R. Bartlett, and S. W. Wilson, "An annotated checklist of the delphacid planthoppers (Hemiptera: Delphacidae) of Florida with the description of three new species and the new genus Meristopsis," Florida Entomologist, vol. 95, no. 2, pp. 395-421, 2012. 


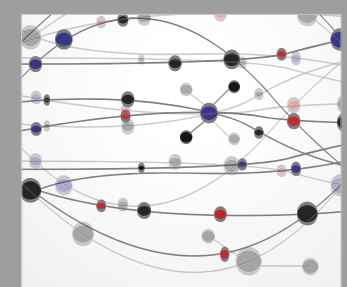

The Scientific World Journal
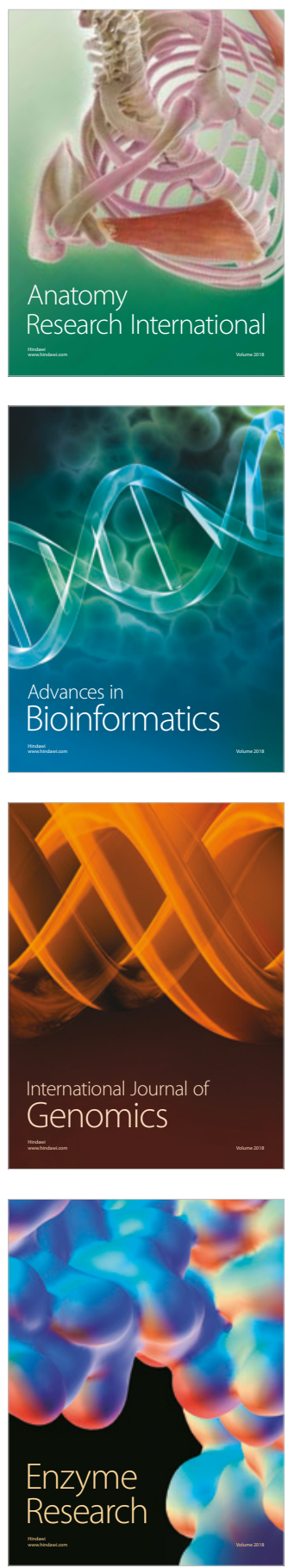
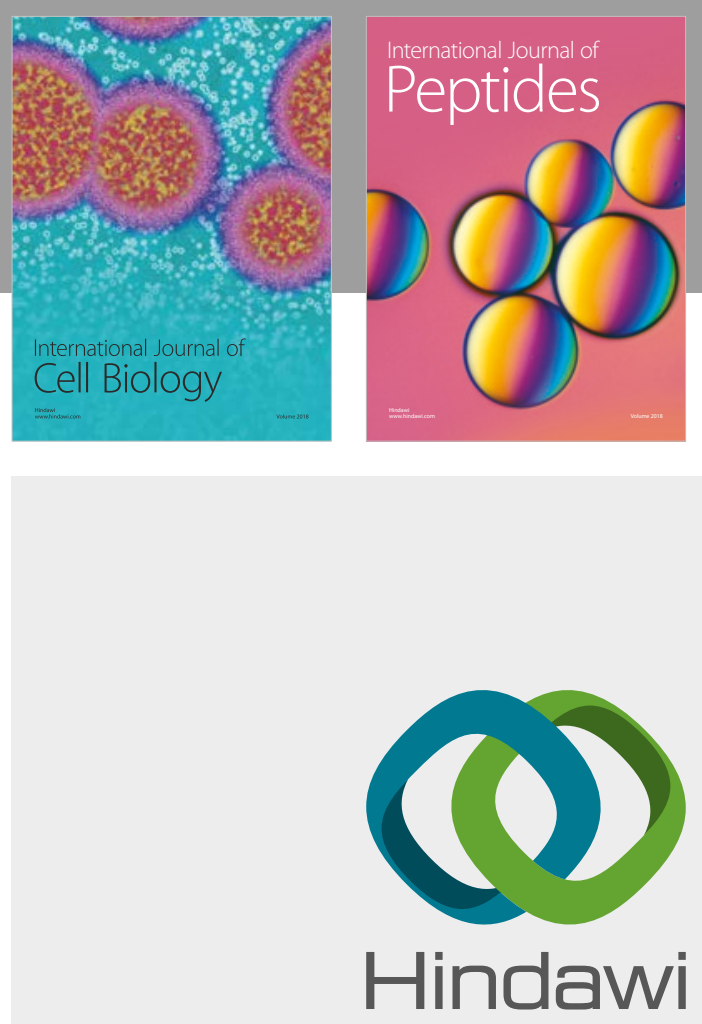

Submit your manuscripts at

www.hindawi.com
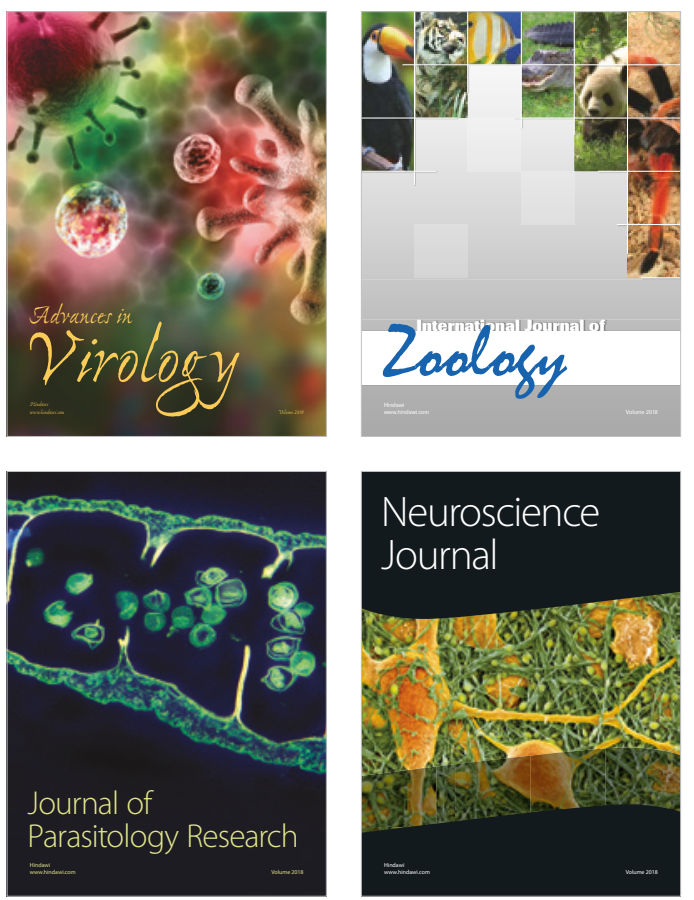
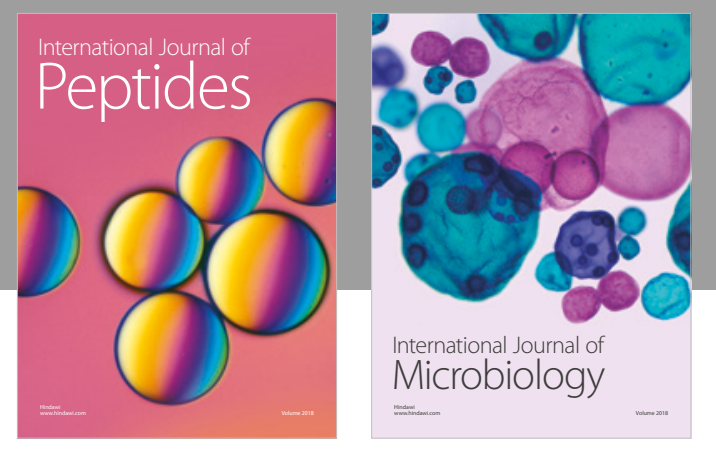

nternational Journal of Microbiology
Journal of
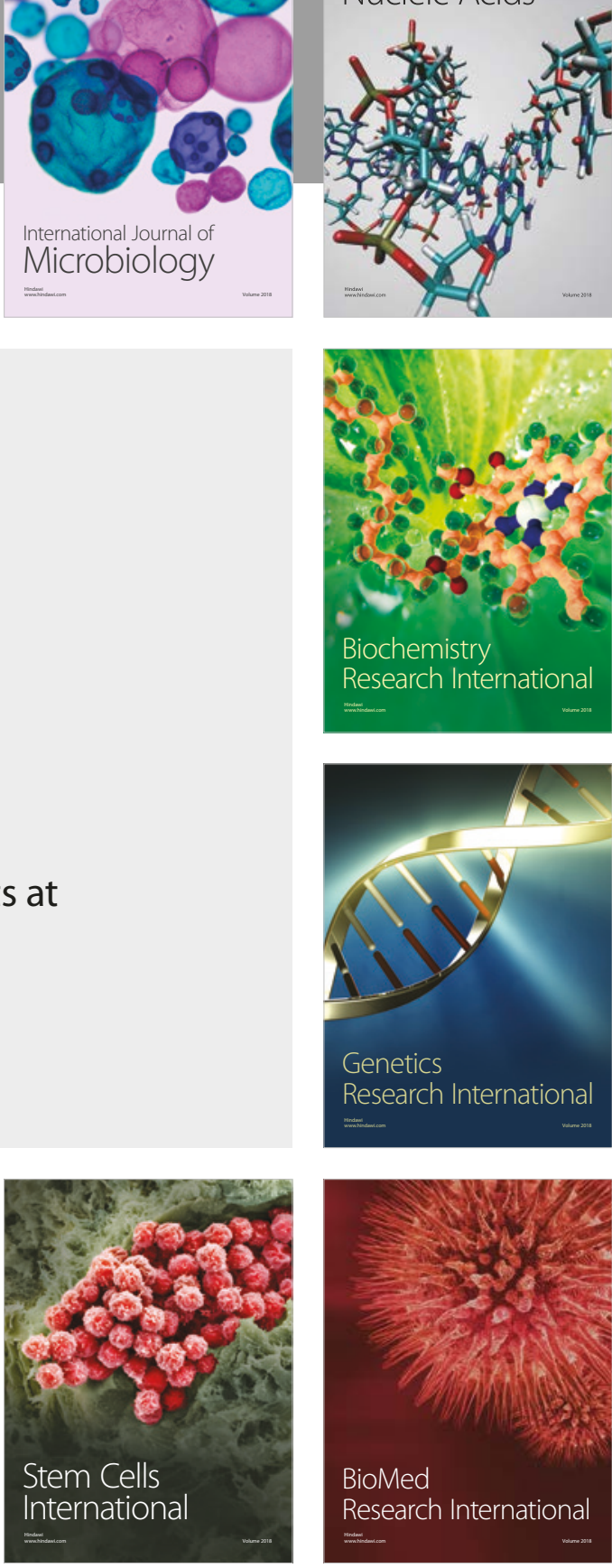
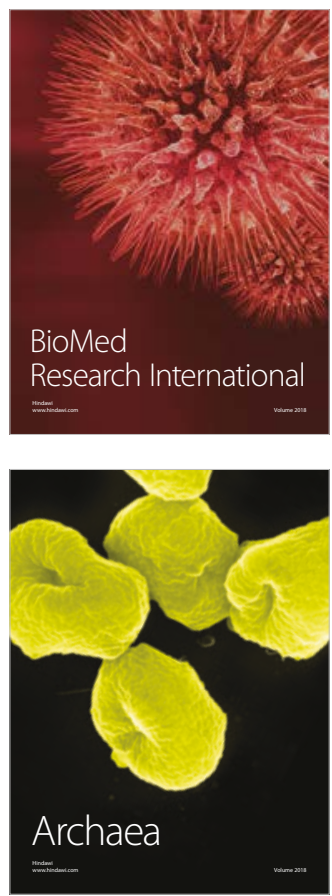